\title{
Review on Aggregatum Onion (Allium cepa L. var. aggregatum Don.)
}

\author{
T. Saraswathi ${ }^{1}$, V.A. Sathiyamurthy ${ }^{2 *}$, N.A. Tamilselvi ${ }^{2}$ and S. Harish ${ }^{2}$ \\ ${ }^{1}$ Horticultural Research station, Kodaikanal-624 103, India \\ ${ }^{2}$ Department of Vegetable Crops, Horticulture College and Research Institute, Tamil Nadu \\ Agricultural University, Coimbatore-641 003, India \\ *Corresponding author
}

\section{A B S T R A C T}

The genus Allium contains seven cultivated species of economic importance: the bulb onion (Allium cepa), aggregatum onion (A. cepa var. aggregatum $\mathrm{L}$ ), shallot (A. cepa var. ascalonium), chive (A. schoenoprasum), Chinese chive (A. tuberosum), Japanese bunching onion (A. fistulosum), garlic (A. sativum), Leek (A. ampeloprasum var. porrum) and rakkyo (A. chinence). Of which, aggregatum onion Allium cepa var. aggregatum Don

\section{Keywords}

Aggregatum

Onion,

Allium cepa L.

Article Info

Accepted:

15 March 2017

Available Online:

10 April 2017 $(2 n=16)$ is one of the important species of Allium vegetables as it forms an indispensable part of many diets, both vegetarian and non-vegetarian. Onion is valued for its bulbs having characteristic odour, flavor and pungency. It is an export oriented vegetable and earns a valuable foreign exchange to our country. It is known by different names such as small onion, potato onion, underground onion, shallots, multiplier onion, nesting onions, ever-ready onion. The bulb is anthelmintic, anti-inflammatory, antiseptic, antispasmodic, carminative, diuretic, expectorant, febrifuge, hypoglycaemic, hypotensive, lithontripic, stomachic and tonic. When used regularly in the diet it offsets tendencies towards angina, arteriosclerosis and heart attack. It is also useful in preventing oral infection and tooth decay. Baked onions can be used as a poultice to remove pus from sores. Fresh onion juice is a very useful first aid treatment for bee and wasp stings, bites, grazes or fungal skin complaints. It also aids the formation of scar tissue on wounds, thus speeding up the healing process, and has been used as a cosmetic to remove freckles. This plant has broadspectrum activities, so that this review focuses on potential uses, Nutritive profile of the bulb, Area, production and export, systematics, Botany, Varietal wealth, package of practices, post harvest management, Seed production and Plant protection aspects of the crop.

\section{Introduction}

Aggregatum onion (Allium cepa L. var. aggregatum Don.) is one of the oldest bulb crops known to mankind and extensively grown and consumed in Southern states of India. On global scale aggregatum onion is a minor bulb crop however in South East Asia especially in India it is a highly remunerative crop.
The bulblets of aggregatum onion are smaller than bulbs of common onion (Allium cepa $\mathrm{L}$ ). Sometimes the flowers are formed in aggregatum onion but cultivation is extensively by vegetative means (bulblets) contrast to common onion. It is famous for its pungency and reproduces primarily by division of bulbs, rather than by seed. 
This makes it more similar to garlic than to common onions. It is a crop of tropical and subtropical region which are tolerant to hot and humid tropical climate, better tolerance to pest and diseases and have longer storage life than the common onion.

It is also known as small onion, potato onion, underground onion, shallots, multiplier onion, nesting onions, ever-ready onion and Egyptian ground onion noted for its hardiness and early maturity than the common onion. All the varieties of small onion do not produce seeds but $\mathrm{CO}(\mathrm{ON} 5)$ propagated through seeds as well as bulblets. Small onions are widely used in the south Indian kitchen mainly for seasoning of curries and preparation of different types of sambar, a lentil-based dish. Small onion pickles in red vinegar are common in many Indian restaurants, served along with sauces and papad on the condiments tray. In India it is used as a home remedy for sore throats by eating with jaggery or sugar. In Nepal, these are used as one of the ingredients for making momo. In Iran, grated shallot mixed with dense yogurt, a combination served in almost every restaurant.

\section{Uses}

It contributes significant nutritional value to the human diet and has medicinal properties. It is primarily consumed for their unique flavour or for their ability to enhance the flavour of other foods because of the presence of volatile compound known as allyl-propyl disulphide (Randle, 2000). Small onion bulb is used as food, spice and seasoning of curries. It stimulates the appetite. It is often used raw, sliced, mixed with soy sauce and eaten with roasted meat. It can be mixed with other ingredients and after grinding used as a spice for meat or fish. It is used for pickling, cooking and frying.

\section{Nutritional value of small onion per $100 \mathrm{~g}$}

\begin{tabular}{|c|c|}
\hline Energy & : $301 \mathrm{~kJ}(72 \mathrm{kcal})$ \\
\hline Carbohydrates & : $16.8 \mathrm{~g}$ \\
\hline Sugars & $: 7.87 \mathrm{~g}$ \\
\hline Dietary fiber & : $3.2 \mathrm{~g}$ \\
\hline Fat & $: 0.1 \mathrm{~g}$ \\
\hline Protein & : $2.5 \mathrm{~g}$ \\
\hline Vitamin B1 (Thiamine) & $: \quad 0.06 \mathrm{mg}(5 \%)$ \\
\hline Vitamin B2 (Riboflavin) & $: \quad 0.02 \mathrm{mg}(2 \%)$ \\
\hline Vitamin B3 (Niacin) & $: \quad 0.2 \mathrm{mg}(1 \%)$ \\
\hline Vitamin $\mathrm{B}_{5}$ (Pantothenic acid) & $: \quad 0.29 \mathrm{mg}(6 \%)$ \\
\hline Vitamin $\mathrm{B}_{6}$ & $: \quad 0.345 \mathrm{mg}(27 \%)$ \\
\hline Vitamin $B_{9}(\underline{\text { Folate }})$ & $: \quad 34 \mu \mathrm{g}(9 \%)$ \\
\hline Vitamin C & : $8 \mathrm{mg}(10 \%)$ \\
\hline Calcium & : $37 \mathrm{mg}(4 \%)$ \\
\hline Iron & : $\quad 1.2 \mathrm{mg}(9 \%)$ \\
\hline Magnesium & : $21 \mathrm{mg}(6 \%)$ \\
\hline Manganese & : $0.292 \mathrm{mg}(14 \%)$ \\
\hline Phosphorus & : $60 \mathrm{mg}(9 \%)$ \\
\hline Potassium & : $334 \mathrm{mg}(7 \%)$ \\
\hline Zinc & : $0.4 \mathrm{mg}(4 \%)$ \\
\hline
\end{tabular}


Young inflorescences are popular vegetable where the climate does not preclude bolting. It also has medicinal properties. Traditionally it is used to reduce fever and to cure wounds.

In the latter case the bulb is sliced, mixed with coconut oil and salt, boiled and placed as a poultice on the wound. Shallot is also used to lower blood sugar levels and inhibit platelet aggregation by eating it raw or cooked, as an extract or powder.

\section{Area, production and export}

Aggregatum onion mainly produced in southern states of India viz., Tamil Nadu, Andhra Pradesh and South Karnataka and small parts of Orissa and Kerala. Tamil Nadu accounted for five per cent of country's area under onion and more than 70 per cent of the area is cultivated by small onion (A. cepa var. aggregatum). Around 90 per cent of country's small onion is produced from Tamil Nadu and 10 per cent from Karnataka.

\section{Taxonomic classification}

$\begin{array}{ll}\text { Kingdom } & : \text { Plantae } \\ \text { Division } & : \text { Angiosperm } \\ \text { Class } & : \text { Monocots } \\ \text { Order } & : \text { Asparagales } \\ \text { Family } & : \text { Alliaceae } \\ \text { Genus } & : \text { Allium } \\ \text { Species } & : \text { Cepa } \\ \text { Variety } & : \text { Aggregatum }\end{array}$

(Anon., 2013)

Vernacular names of aggregatum onion in India

Tamil

English

Hindhi, Marathi, Marwari and Punjabi

Malayalam

Bengali

Kashmiri

Nepali

French
: Chinna vengayam or Sambar vengayam

: Small onion, Shallots, Multiplier onion

: Kanda or Gandana or Pyaaz

: Cheriya ulli or Chuvanna ulli

: Gundhun

: Praan

: Chyapi

: Echalote, oignon patate

\section{Vernacular names of aggregatum onion on global level}

$\begin{array}{ll}\text { Indonesia } & : \begin{array}{l}\text { Bawang merah, Brambang (Javanese), Bawang beureum } \\ \text { (Sundanese) }\end{array} \\ \text { Malaysia } & : \text { Bawang merah, bawang kecil } \\ \text { Papua New Guinea } & : \text { Lip anian } \\ \text { Philippines } & : \text { Sibuyas tagalog (Tagalog), lasona (Bisaya), cebollas } \\ \text { Cambodia } & : \text { Kicol) } \\ \text { Laos } & : \text { Hoom bwàx } \\ \text { Thailand } & : \text { Hom, hom-daeng (central), hom-lek (central) } \\ \text { Vietnam } & : \text { Hành ta, hành tăm, hành nén. }\end{array}$

(Anon., 2013) 


\section{Botany}

Both Kerala and Tamil Nadu together consumption and exports accounts total small onion produced in Tamil Nadu. In Tamil Nadu major small onion growing districts are Perambalur, Trichy, Coimbatore, Tiruppur, Namakkal and Dindigul, Erode, Thirunelveli and Thoothukudi. It was exported to Sri Lanka, Malaysia and Gulf Countries (Anon., 2013). According to the National Horticultural Board, in Tamil Nadu aggregatum onion was grown in 0.38 lakh hectares and produced 4.29 lakh tonnes in 2012-13.

Onion is a biennial crop, storing food in the bulb during the first season and flowering in the second season, when the days become long and warm enough.

\section{Root}

The root system is shallow and fibrous.

\section{Leaf}

Each leaf consist of two main parts: a sheathing leaf base and a hollow, linear, semicylindrical and flattened blade on the upper side, both separated by short membranous ligules. It grows up to $40 \mathrm{~cm}$ long and up to 1 $\mathrm{cm}$ in diameter.

\section{Bulb}

The bulb consists of a short plate- like stem surrounded by a number of concentric layers of fleshy leaf bases. The outer leaf bases are thin, fibrous and dry, forming a protective covering or 'tunic', around the inner fleshy ones, which are laden with food. The innermost leaves also have thickened leaf bases but with aborted lamina. Towards the end of the first season growth, the apical meristem or shoot apex grows to produce a leafless flowering stalk the 'scape' $30-60 \mathrm{~cm}$ tall, which pushes up through the centre of the pseudo stem formed by the sheathing leaf bases. The scape is hollow, cylindrical, swollen near the middle, tapering towards the end and gathered in clusters which are $2-5 \mathrm{~cm}$ in diameter.

\section{Flowers}

The inflorescence is an umbel, $3-5 \mathrm{~cm}$ in diameter. It is an aggregate of many smaller inflorescences of 5 to 10 flowers each. Within each of these small cymes of inflorescence, the flowers open in a definite sequence and with a considerable delay between successive flowers. Because the whole inflorescence of onion consists of a dozen of small inflorescence, the flowers of umbel appear to open quite irregularly. Flower opening takes place over a period that may be as long as two weeks or more. A single plant producing several inflorescences may have flower opening for a 'month or longer'.

The ovary is superior, three loculed with nectar at the base. Three united carpels are situated at the centre of the ovary. The next whorl has three stamens (inner whorl) followed by three outer stamens. The three inner ones are alternated by three outer stamens. The next whorl is formed by three inner perianth segments alternating to outer stamens. This is surrounded by three outer perianth segments which alternate the inner segments. This pistil contains three compartments or locules each of which contains two ovules. In each of septa or wall separating the compartments of ovary lies a mass of nectar tissues which opens to the surface by a pore under a flap of tissue on the outer wall of the ovary. As the nectar tissue is between the locule of ovary they stand opposite to 3 inner stamens. These stamens have much broader filaments than those of outer whorl which facilitates transfer of pollen grains through the body of the insects 
like honeybee which visit the necatrine glands.

\section{Floral biology}

Flowering in onion is induced by specific environmental conditions. When the weather factors are favourable, the shoot apex ceases to produce leaf primordia and initiate inflorescence. When 'spathe' first forms, it looks much like a primordium or a single foliage leaf. But internodes below the foliage soon starts to elongate and consequently inflorescence is easily recognized. The peduncle is an apical extension of the stem and region between inflorescence bract (spathe) and uppermost foliage leaf is the only internode which elongates during the entire life of the plant. Like the leaf blade, the inflorescence stalk of common onion is at first a solid structure but through difference in growth, it becomes thin walled and hollow as it increases in size. The number of flower stalks produced by a single onion plant may vary from one to over a dozen. Each inflorescence is produced at the apex of an axis.

Anthesis starts at 7 a.m. and continues upto 1 p.m. The phenomenon of 'protandry' makes the flowers mostly cross pollinated or out breed. The anthers of inner whorl dehisce first and shed pollen followed by anthers of outer stamen and all of the pollen being shed over a period of 2 to 3 days. The style begins to elongate slowly when the flower opens but reaches its full length only after all the pollen have been shed. Then the stigma becomes receptive viz., 14 hours after anthesis. The receptivity of the stigma lasts for 34 hours. While the delay in the receptivity of stigma may reduce self pollination of single flower, but insects readily transfer pollen grains among flowers with in an umbel and between umbels of same plant. The fruit is a globular capsule and the seeds are black.

\section{Propagation}

The aggregatum onion Allium cepa var. aggregatum produces small bulbs which form an aggregated cluster and is propagated through bulblets and also by seeds. The cultivated varieties $\mathrm{CO} 1, \mathrm{CO} 2, \mathrm{CO} 3, \mathrm{CO} 4$ and MDU 1 are propagated by bulblets only, since they are not produced any seeds. While the variety $\mathrm{CO}(\mathrm{On}) 5$, produced seeds and propagated by both bulblets and also seed.

\section{Varietal wealth}

Tamil Nadu Agricultural University is one of the pioneer Institutes working in small onion. Research on small onion had been started as early as 1970 and due to continuous efforts, six varieties have been released from Tamil Nadu Agricultural University, Coimbatore in small onion. The details are;

\section{CO 1}

It is a clonal selection from CS 450 an onion type introduced from Manachanallur released during the year 1965. The crop duration is 90 days and yields about $10 \mathrm{t} / \mathrm{ha}$. Bulbs are medium in size, red in colour. The bulb weight per plant is 55 to $60 \mathrm{~g}$ with an average 8 bulbs per plant. The plant is medium in height $(30 \mathrm{~cm})$ with green leaves. It is fairly pungent with a medium TSS content $\left(8-9^{0}\right.$ brix).

\section{$\mathrm{CO} 2$}

It is a selection from germplasm type CS 911. The crops yields $12 \mathrm{t} / \mathrm{ha}$ in 65 days, the bulbs are crimson in colour and moderately bigger in size. The bulb weight per plant ranges from 60 to $65 \mathrm{~g}$. with an average of 9 bulbs per plant. The leaves are green with cylindrical shape. The plant height is $30 \mathrm{~cm}$. The number of shoots per plant ranges from 7 to 9 . The weight loss during storage is lesser than CO 1. This variety is pungent with high TSS content 
$\left(12^{0}\right.$ brix), this variety resistant to burple blotch.

\section{CO 3}

It is a clonal selection from the open pollinated progenies of CS 450 and resistant to thrips. The crop duration is 65-70 days and yields $15.8 \mathrm{t} / \mathrm{ha}$. The bulbs are pink in colour and bolder in size. The bulb length and girth are $3.5 \mathrm{~cm}$ and $8.3 \mathrm{~cm}$ respectively. The mean bulb weight per plant is $75 \mathrm{~g}$. The number of bulbs per plant ranged from 8 to 10 . The plant has light green erect cylindrical leaves. The plant height is $40 \mathrm{~cm}$. The number of shoots ranges from 6 to 8 . The bulbs are bigger than CO 2 with good consumer appeal. The plants are moderately resistant to thrips. The bulbs store well for 120 days devoid of sprouting in well ventilated store rooms. The variety contains $17.5 \%$ dry matter with $0.53 \%$ sulphur and $13.0^{\circ}$ brix TSS.

\section{MDU 1}

It is a selection from the Sempatti local. This variety has uniform big sized bulbs with bright red colour and better keeping quality without any weight loss. Its yield potential is $13 \mathrm{t} / \mathrm{ha}$. It is resistant to thrips and tolerant to lodging due to thick erect leaves.

\section{CO 4}

It is a hybrid derivative of the cross AC $863 \mathrm{x}$ $\mathrm{CO} 3$ and resistant to thrips. The crop duration is 65 days. It yields $19 \mathrm{t} / \mathrm{ha}$. The leaves are light green, erect and cylindrical. The number of bulbs per plant varies from 8 to 13 with an average weight of $90 \mathrm{~g}$ per clump. Bulbs are attractive light pink bold in size with good consumer appeal. The bulbs store well over 150 days.

\section{CO (On) 5}

It is a high yielding variety developed by mass pedigree method of selection. This variety has the ability of free flowering and seed set throughout Tamil Nadu. It possesses high bulb yield $18.9 \mathrm{t} / \mathrm{ha}$ (18.8 per cent higher than $\mathrm{CO} 4$ ) in a crop duration of 90 days. It is free flowering type with seed setting ability of $250-300 \mathrm{~kg} / \mathrm{ha}$ and so it is propagated through seeds. March - July for bulb production and November - January for seed production. It possesses attractive pink coloured bold size bulbs. The total soluble solids content is 13 ${ }^{0}$ brix. The pungency principle measured as pyruvic acid is $2.37 \mu \mathrm{g} / \mathrm{g}$ of fresh weight.

\section{Agrifound red}

This variety was released from National Horticulture Research and Development Foundation, Nasik, Pune. This variety recommended for cultivation in Kharif and Rabi season in Tamil Nadu, Karnataka and Kerala. Average size of cluster is $7.15 \mathrm{~cm}$ with average weight of 65-67 g. Average numbers of bulblets per cluster is 5-6. Colour of bulblets is light red. This variety matured in 65-67 days after planting.

\section{Arka ujjwal}

It is a multiplier onion variety with uniform bright dark red bulb color, compound bulb with flat shape, bulb size $4-5 \mathrm{~cm}$,number of bulblets/bulb 3-5, bulb weight 40-45g, TSS $16-18 \%$,dry matter content $14-16 \%$ and bulb yield $20-25$ t/ha in 85 days.

Genetic diversity study done by Sundaram (2012) using 23 RAPD primers with 25 genotypes collected from diverse localities indicated the high level of polymorphism (75.20\%) among the genotypes. Maximum diversity was noticed between Aca 16 and Aca 24. The dendrogram constructed from the data of twenty five genotypes revealed four distinct clusters. The grouping of genotypes based on geographical area of adoption to some extent was demonstrated for few genotypes. The germplasm displayed a 
relatively low genetic diversity, when the materials are originated from the same geographical location were grouped into the same cluster.

\section{Agronomic practices}

Aggregatum onion or shallots are very productive and easy to grow. Aggregatum onion invariably forms a cluster of new bulbs, often as many as 10 or 15 per cluster. Some throw up a flower stalk, but generally this should be removed as soon as it is noticed.

\section{Climate and soil}

It comes up very well under tropical conditions with sufficient soil moisture. Heavy rains during germination as well as bulb formation are deleterious to crop growth. It grows very well between a $\mathrm{pH}$ range of 6-7. Well drained loamy soils are the best suited while in clayey soil, the bulb formation is hindered.

\section{Season}

Onion is highly sensitive to temperature and photoperiod. Difference in onion yield is caused by different planting times of the year (Boyhan et al., 2009). In Tamil Nadu, It is being cultivated throughout the year. The best season for planting of small onion bulbs are April - July, October-November and January - March. Heavy rains and extreme winter are not favourable for this crop.

\section{Seeds and seed rate}

A quantity of $1200 \mathrm{~kg}$ of seed bulbs (medium sized bulbs) or bulblets would be required to plant one hectare. The bulblets are planted on ridges. The distance between the ridges is 30$45 \mathrm{~cm}$ and between bulblets is 10-15 cm. Bulb or bulblet size play an important role in formation of flower stalks. Selection of big mother bulbs instead of medium or small size has significant influence on the formation of flower stalks in small onions. The amount of available resources may be the influential factor on inducing the formation of more flower stalks in onions. After the completion of the resting period it becomes smaller due to rapid deterioration of scales, in which food is stored. Longer storage period reduces stored resources of sets resulting poor quality material. Sumanaratne and Palipane (2002) observed when cultivated with poor quality material more number of weak sprouts were formed instead of few vigorous sprouts, resulting absence of lower stalks. The bulb size of more than $3 \mathrm{~cm}$ is ideal for planting. The results are furnished below.

\begin{tabular}{|l|l|l|}
\hline Mother bulb size & $\mathbf{1 9 9 4 - 9 5}$ & $\mathbf{1 9 9 6 - 9 6}$ \\
\hline Big $(>3 \mathrm{~cm})$ & 40 & 47 \\
\hline Meidum $(2-3 \mathrm{~cm})$ & 17 & 19 \\
\hline Small $(<2 \mathrm{~cm})$ & 07 & 06 \\
\hline
\end{tabular}

The other method of propagation is through seeds. Though most of the varieties are propagated by bulbs, the Department of vegetable crops, Horticultural College and Research Institute (HC \&RI), Tamil Nadu Agricultural University (TNAU), Coimbatore, have developed CO (On) 5- new seed propagated aggregatum onion (small or country onion) variety. For seed propagation, $2.5 \mathrm{~kg}$ seeds are required for planting one hectare.

\section{Seed treatment}

Selvarani and Umarani (2011) reported that among the four methods of priming [hydro priming, sand matric priming, halo priming 
and osmo priming), sand matric priming (80\% water holding capacity (WHC)] for 24 hours recorded maximum improvement in speed in emergence and germination Percentage $(58 \%)$ and which is 7 percentage higher than the control.

\section{Nursery}

Raised beds of $1 \mathrm{~m}$ width and convenient length have to be formed. Onion seeds have to be sown in the lines marked with the spacing of $10 \mathrm{~cm}$ between and covered with sand or FYM. Then the beds have to be mulched with dry grass. Immediately after sowing, watering should be done with rose can. Regular watering should be done twice in a day. A firm, moist soil is required around the onion seed even under the optimum conditions. The seedlings will germinate five days after sowing. When all the seeds are germinated the mulch has to be removed. The seedlings will be ready for transplanting after 45 days of sowing. When soils are cold and wet, germination may take up to 30 days. Crusty soils can reduce plant numbers especially where seed vigour is not strong.

\section{Preparatory cultivation and fertilizer requirement}

The soil should be ploughed two to three times to make the soil into fine tilth. At the time of last ploughing, about $25 \mathrm{t}$ of FYM Azospirillum $2 \mathrm{~kg}$ and Phosphobacteria 2 $\mathrm{kg} / \mathrm{ha}$, NPK @ 30:60:30 kg/ha is incorporated into the soil as basal. Remaining $30 \mathrm{~kg} \mathrm{~N}$ is applied 30 days after planting of bulbs or seedlings. A quantity of $30 \mathrm{~kg}$ of nitrogen, 60 $\mathrm{kg}$ of phosphorus and $30 \mathrm{~kg}$ of potash are mixed and applied in a band near the ridges (on both sides of the ridges) and thoroughly mixed with the soil.

Subbiah et al., (1982) reported that, per cent increases in yield of $\mathrm{CO} 2$ aggregatum onion is achieved byapplying 60:60:30 kg NPK/ha.
Jawaharlal et al., (1985) recommended 60:60:30 kg NPK/ha along with zinc sulphate and ferrous sulphate each at $50 \mathrm{~kg} / \mathrm{ha}$ to obtain bulb yield of $17.1 \mathrm{t} / \mathrm{ha}$. In $\mathrm{CO} 4$ aggregatum onion, more bulb yield associated with better recovery of large sized bulbs and longer storage period can be obtained by application of $75: 75: 75 \mathrm{~kg}$ NPK/ ha (Jayabharathi, 1989). Contrary to this report, Thilakavathy and Ramaswamy (1998) reported that application of 45:45:30 kg NPK /ha along with Azospirillum and phosphobacteria to $\mathrm{CO} 4$ aggregatum onion gave highest plant height $(49.1 \mathrm{~cm})$, number of leaves (46.33) and yield (18.37 t/ha) and maximum shape index (3.36). Muthuramalingam et al., (2000) reported that combined application of $60: 60: 30 \mathrm{~kg}$ of NPK/ha along with FYM @ 25t/ha, Azospirillum @2 t/ha and Phosphobacteria @ $2 \mathrm{~kg} / \mathrm{ha}$ significantly influence the quality parameters like TSS $\left(17.12^{\circ}\right.$ brix), ascorbic acid (11.07 mg/100g) and pyruvic acid content $(4.26 \mu \mathrm{g} / \mathrm{g})$. Santhi et al., (2005) studied the effect of soil fertility and Integrated Plant Nutrition System (IPNS) on the yield of onion (var. CO 4) in Typic Ustropept soils of Tamil Nadu. The bulb yields as well as uptake by onion increased with increase in dose of fertiliser $\mathrm{N}, \mathrm{P}_{2} \mathrm{O}_{5}$ and $\mathrm{K}_{2} \mathrm{O}$ and also with application of FYM and Azospirillum and concluded that soil fertility and IPNS had profound influence on the bulb yields and nutrient uptake pattern of aggregatum onion.

Micronutrients play an important role in the plant metabolic processes from cell wall development to respiration, photosynthesis, chlorophyll formation, enzymes activity, nitrogen fixation etc. (Ballabh and Rana, 2012). Zinc is a vital component mainly recommended for sodic soils reclamation. Deficiency of boron occurs widely in highly calcareous soils of Bihar, parts of Gujarat and Tamil Nadu. Indian soils are exposed to multi-micronutrient deficiencies that closely 
associated with the yield and quality of crops. Particularly, zinc deficiency is widely prevalent and it has been estimated that $60 \%$ of soils in India and more than $70 \%$ of soils of Tamil Nadu are found to be deficient. Therefore, micronutrient fertilizer is essential to achieve the targeted yield. Alam et al., (2010) reported that foliar application of micronutrients significantly influences the plant growth, yield and quality of onion. Umesh Acharya et al., (2015a \& b) reported that the highest plant height, number of leaves per plant, leaf girth, fresh leaf weight, fresh bulb weight, total dry matter production, bulb yield per plot and bulb yield per hectare. The quality parameters viz., Ascorbic Acid, total chlorophyll content, total dry matter production and maximum benefit: cost ratio was recorded by $0.5 \%$ foliar spray of zinc sulphate at 30 and 45 days after transplanting (DAT), while soil application of borax at 10 $\mathrm{kg} \mathrm{ha}{ }^{-1}$ showed highest polar, equatorial diameter and highest number of bulblets per clump. The highest TSS content was observed with soil application of zinc sulphate at $10 \mathrm{~kg}$ $\mathrm{ha}^{-1}$.

\section{Transplanting}

There are two methods of planting are practiced. One is ridges and furrow method and the other is flat bed system. In the ridges and furrow method, ridges and furrows are formed $45 \mathrm{~cm}$ apart. The bulbs are planted in a spacing of $10 \mathrm{~cm}$ apart on both the sides of the ridges. A study conducted by Muthuramalingam et al., (2000) in seed setting aggregatum onion revealed that under ridges and furrow system, closer spacing (45 x $5 \mathrm{~cm}$ ) significantly influence the quality parameters like TSS, ascorbic acid and pyruvic acid content. In the flat bed system, 3 x $2 \mathrm{~m}$ size flat beds are formed and bulbs or seedlings are planted at a spacing of $15 \times 10$ $\mathrm{cm}$. The field should be irrigated immediately after planting and again on the third day. Then the field is irrigated once in 7 to 10 days depending on the soil moisture.

\section{Drip and Fertigation system}

Small onion can also be cultivated under drip and fertigation system. For this $1.20 \mathrm{~m}$ width and $0.30 \mathrm{~m}$ height raised bed has to be formed. Drip laterals with drippers at spacing of $30 \mathrm{~cm}$ have to be laid along the raised bed. Overnight wetting should be given to the beds. Then bulbs or seedlings have to be planted at a spacing of $15 \times 10 \mathrm{~cm}$ in 6 rows. Tamil Nadu Agricultural University, Coimbatore has standardized the fertigation schedule for small onion cultivation under drip and fertigation system. From the recommended dose of fertilizers $(60: 60: 30 \mathrm{~kg}$ NPK / ha), $75 \%$ of $\mathrm{P}_{2} \mathrm{O}_{5}$ should be applied as basal during last ploughing. The remaining quantity of fertilizers should be applied through fertigation as per the schedule mentioned below.

\begin{tabular}{|l|l|l|l|l|l|}
\hline S.No & Crop stage & Duration & \multicolumn{3}{|l|}{$\%$ requirement } \\
\cline { 5 - 7 } & & in days & N & P & K \\
\hline 1. & Sowing to establishment stage & 10 & 10 & 20 & 10 \\
\hline 2. & Vegetative stage & 25 & 30 & 30 & 20 \\
\hline 3 & Bulb formation stage & 25 & 30 & 30 & 30 \\
\hline 4 & Bulb development stage & 30 & 30 & 20 & 40 \\
\hline & Total & $\mathbf{9 0}$ & $\mathbf{1 0 0}$ & $\mathbf{1 0 0}$ & $\mathbf{1 0 0}$ \\
\hline
\end{tabular}

In $\mathrm{CO}$ (On) 5, fertigation with 75 per cent recommended dose of fertilizers (i.e., 45: 45: $22.5 \mathrm{~kg}$ of NPK / ha) registered higher bulb yield (8.34 and 11.05 t/ha) 
compared to soil application. The higher bulb yield is due to increased plant height, number of leaves and root length, leaf area index, total chlorophyll content and dry matter content. Quality parameters like TSS, pyruvic acid, ascorbic acid, protein and total sugar content values were also high in fertigation with 75 per cent recommended dose of fertilizers.

The nutrient uptake pattern also got increased with 75 per cent recommended dose of fertilizer under fertigation system. Based on the economic analysis, application of 75 per cent RDF (i.e., 45: 45:22.5 kg of NPK/ha) through straight fertilizer viz., urea, SSP and SOP recorded the highest benefit cost ratio (3.20 and 4.24) than the other treatments and it can be recommended for small onion cultivation (Savitha, 2009).

\section{Weed management}

Onion exhibits greater susceptibility to weed competition as compared to other crops due to its inherent characteristics such as their slow growth, small stature, shallow roots and lack of dense foliage. Spraying of pre-emergence herbicides keeps the crop in weed free conditions during the early stages. At later stage, second flush of weeds will affect the bulb formation. Hand weeding helps to keep the weed population below economic threshold level throughout the crop growth period. At later stage, second flush of weeds will affect the bulb formation. Hand weeding helps to keep the weed population below economic threshold level throughout the crop growth period.

Dhananivetha et al., (2017) recommended application of early post emergence maybe helpful to reduce damage to the bulb, weed competition and cost of weeding. Chemical weed control is also practiced in place of manual weeding. Application of pre emergent weedicide pendimethilin (30\% EC) @ 4-5 $\mathrm{ml} / \mathrm{l}$ or oxyflurofen (23.5\% EC) @ 1.5-2ml/1 just after planting and one or two hand weeding is recommended to control the weeds in small onion

\section{Intercropping}

Aggregatum onion is a short duration garden land crop and responds well to intercropping system with long duration crops like banana and sugarcane. Misra (2000) reported increased total productivity by intercropping of onion with sugarcane. Mahadevaswamy and James Martin (2003) reported that adopting $120 \mathrm{~cm}$ wide row spacing for sugarcane and planting of aggregatum onion as intercrop at high density (1:4 ratio) recorded the maximum productivity and economic returns compared to normal row spacing $(90 \mathrm{~cm})$ and low density planting $(1: 2)$ of onion.

\section{Harvesting}

The crop comes to harvest by ninety days after planting during winter and seventy days in summer. Fifteen days before harvest, the plants are sprayed with $500 \mathrm{ppm}$ of maleic hydrazide so as to enhance the shelf life on the storage house. Anbukkarasi (2010) reported that pre-harvest foliar spray of Maleic hydrazide @ 2000 ppm + carbendazim @ 1000 ppm at 30 days before harvest improved the yield and quality of the bulbs and minimize the post-harvest losses. At the time of maturity, more than $75 \%$ of the leaves will dry up. One week before harvest, the last irrigation is done and the bulbs are harvested.

\section{Post harvest management}

\section{Curing}

Field curing followed by shade curing is done with adequate ventilation. The tops are 
removed and then the bulbs are dried in shade (shade curing) and then stored in a well ventilated storage structure. It helps to protect the bulbs from sun scalding, improves the bulb colour and keeps the outer scale dry.

\section{Storage}

Small onion is an important ingredient of south Indian dishes. But, the onion bulbs are harvested once or twice in a year. To avoid market demand both in domestic and export market and year round supply, the bulbs need to be stored. About 35 to 40 per cent of onion is estimated to be lost during postharvest handling. In general, the losses due to reduction in weight, sprouting and rotting (decay) were found to be 20 to 25,4 to 5 and 10 to 12 per cent respectively (Pandey, 1989; Anon., 1994). Uninterrupted transpiration and respiration during storage causes elevated weight loss and makes the bulb susceptible to various storage diseases. Proper storage structures or of suitable field techniques coupled with storage temperature plays a major role in enhancing the postharvest life and quality of onion. The Directorate of Onion and garlic Research has developed different types of storage structures for storing onion bulbs. Bottom and side ventilated two-row storage structure and low cost bottom ventilated single row storage structure have been recommended. The optimum conditions for storage are $30-35^{\circ} \mathrm{C}$ and $65-70 \%$ relative humidity under ambient condition. These storage structures reduce storage losses by $20-50 \%$ depending upon the period of storage. Farmers are using Low cost bottom and side ventilated single row storage structure made up of bamboo (1-1.5 feet width and convenient length) till they get premium price.

Storage of onion bulbs in cold store with optimum relative humidity extends shelf life of onion bulbs and reduces post-harvest storage losses. Optimal storage temperature in cold storage is $0^{\circ} \mathrm{C}$ with $65-70 \%$ relative humidity. Under these conditions, the storage losses after six months are only about 5\% which is mainly due to moisture loss. Regular monitoring of both temperature and relative humidity in the store are necessary to avoid significant fluctuations in environmental conditions. Very low temperature $\left(<-2^{\circ} \mathrm{C}\right)$ may lead to freezing injury and high temperature $\left(2-25^{\circ} \mathrm{C}\right)$ coupled with high relative humidity $(>75 \%)$ may cause rotting.

Prabinkumar and Visvanathan (2014) studied the effect of storage temperature on respiration rate of aggregate onion (Allium cepa L var. aggregatum Don.) under ambient $\left(28^{\circ} \mathrm{C}\right)$ and refrigerated $\left(5^{\circ} \mathrm{C}\right)$ condition and indicated that respiration rate decreased with decrease in storage temperature that helps to enhance the shelf life of the product. Kaveri and Thirupathi (2014) studied the thermal, textural and quality properties of the fresh and three months stored $\mathrm{CO} 4$ onion bulbs and inferred that specific heat, thermal conductivity and volumetric heat capacity values decreased with increase in storage period and decrease in moisture content. The quality parameters viz., total soluble solids content was high in three months stored onion as compared to fresh sample. The colour of the fresh onion bulb scales changes from purple red to pale red colour after three months of storage and the colour value 'a' was high in fresh sample. The pyruvic acid content of three months stored onion bulbs was low compared to fresh sample. Kaveri and Thirupathi (2015) studied the geometrical properties like size, shape and area of fresh and three months stored aggregatum onion, to design the equipment for processing and storage. The results of this study indicated that storage of the bulbs causes reduction of most the geometrical properties viz., Mass, volume, true density and bulk density whereas the porosity was increased from the fresh and three months stored onion bulbs. 


\section{Packaging}

Spoilage due to inappropriate storage and packaging is also one of the major problems confronted by small onion growers. Adequate and proper packaging protects the bulb from physical (firmness), physiological (weight) and pathological (decay) deterioration. Anbukkarasi et al., (2010) reported that among the different packing and storage treatments, the lowest physiological loss in weight $(5.18 \%)$, sprouting $(0.62 \%)$, rotting $(0.64 \%)$, rooting $(0.00 \%)$ per cent and the highest sulphur $(0.704 \%)$, pyruvic acid $(2.53$ $\left.\mu \mathrm{mol} \mathrm{g}{ }^{-1}\right)$ and ascorbic acid (10.24 mg $100 \mathrm{~g}^{-}$ $\left.{ }^{1}\right)$ contents and the highest shelf life (up to 6 months) were observed in spreading of bulbs in ventilation storage compared to control.

Bulbs are packed in 40-50 kg jute (hessian) bags, gunny bags, plastic netted bags or plastic and wooden baskets for better storage and transportation. Most of the farmers are using plastic/nylon netted bags for domestic as well as export purpose because these bags are more economical, easily available and attractive.

\section{Onion seed production}

The major constraint in the cultivation of aggregatum onion is large quantity of seed bulbs are needed for planting. The cost of planting material (bulbs) occupies nearly 50\% of the total cost of production if the bulbs are expensive. Therefore the alternate way to reduce the cost of production is using seeds as a planting material.

Production of quality seeds is an important factor for successful onion cultivation (Tomar, 2005). The demand for the quality seed is increasing among the farmers, resulting in more area under seed crops (Sumanaratne and Palipane, 2002). Hence, the elite genotypes which exhibit good seed setting ability should be selected for quality seed production. Onion is short duration crop greatly affected by environmental conditions. The yield of crop is influenced by many factors of which cultivars, soil, climate, spacing and planting dates are more important. Temperature and photoperiod play an important role in production of quality onion seeds. Moreover, seed yield is adversely affected by planting of onion bulbs in wrong season. For seed production purpose, planting of bulbs during November is ideal. Aramirtham (2000) reported that planting of $\mathrm{CO}$ (On) 5 bulbs during November months for seed production exhibited increased seed yield (1.53 g / plant), seed yield per hectare $(612.5 \mathrm{~kg})$ and 100 seed weight $(0.250 \mathrm{~g})$ when compared planting in other months. Contrary to this result, Rohini (2011, $2015 \mathrm{a} \& \mathrm{~b}$ and 2016) reported that among the three genotypes [CO (On) 5, Puttarasal type and Santhaipadugai local], and four planting seasons (September, October, November and December), Puttarasal genotype planted in September season registered the highest bulb and seed yield per unit area with good seed quality under Coimbatore condition. The genotype Santhaipadugai local planted during September season recorded significantly higher total soluble solid ( $14.37^{\circ}$ brix) content and ascorbic acid content ( $9.43 \mathrm{mg} 100 \mathrm{~g}-1$ ). The highest seed protein content was recorded in Puttarasal type (19\%) during September season.

Ponnuswami and Thamburaj (1996) reported that closer spacing $(15 \times 15 \mathrm{~cm})$ instead of 30 $\mathrm{cm} \times 15 \mathrm{~cm}$ (recommended for big onion seed production) yielded $250 \mathrm{~kg}$ of true seeds per hectare. The nets used to prevent lodging of flower stalk had contributed for good seed yield throughout the experiments. The vernalization has significant influences on the flowering of some varieties. The vernalization has significant influences on the flowering of some varieties. When the seed sets are 
subjected to vernalization, it breaks the dormancy and enhance early flowering.

Flowering in onion was mainly induced by low atmospheric temperature ranging from 4 to $15^{\circ} \mathrm{C}$ further, higher temperature after floral initiation sometimes prevent normal development of flower stalks due to abortion of flower initials which leads to low seed yield per unit ${ }^{-1}$ area (Brewster,1994). Use of plant growth regulators in onion crop alters the physiology of crop growth and influences the storage life of bulbs and seeds besides affecting seed quality. Attempts have been made to induce flowering in onion through foliar spray with chemicals and growth regulators (Nehra et al., 1992).To achieve higher productivity, the mother plants could be supplemented with nutrients through foliar sprays which will reduce the loss through absorption, leaching and other processes associated with soil application (Vasilas et al., 1980). Geetharani et al., (2008) reported that, spraying of NAA $(100 \mathrm{ppm})$ at first flower stalk emergence and second spray at 10 per cent flowering stage (i.e. 35 and 45 DAP) enhanced seed recovery and yield by 22.7 per cent. The improvement of seed germination and vigour index due to NAA over control was 16 and 55 per cent, respectively.

\section{Plant protection}

Among the various constraints affecting onion cultivation, biotic stress due to pests and diseases cause huge economical loss, besides reducing the yield and quality (Madhavi et al., 2012). The major pests of aggregatum onion viz., thrips (Thrips tabaci L.), leaf miner (Liriomyza sp.), onion fly and cutworm (Spodoptera litura F.) and diseases viz., purple blotch (Alternaria porri (Ellis) Cif.), basal rot (Fusarium oxysporum f. sp. cepae W. C. Snyder and H. N. Hansen), stemphylium leaf blight (Stemphylium vesicarium), colletotrichum blight /anthracnose/ twister disease (Colletotrichum gleosporiodes), white rot (Sclerotial rot), pink root (Pyrenochaeta terrestris), damping off, downy mildew, black mould, bacterial soft rot, onion yellow dwarf disease and Iris yellow spot disease limit the production and productivity of onion.

\section{Thrips (Thrips tabaci L.)}

T. tabaci is considered as a pest of national importance in India, causing an annual yield loss of 10-15\% through feeding damage and indirectly predisposing purple blotch and transmitting Iris Yellow Spot Virus (IYSV) disease (Gupta et al., 1994; Zen et al., 2008). Eggs are laid only in the tender leaf. The colour of the adult insect varies from pale yellow to grey. The symptoms of the damage are: i) curling and twisting of leaves, if infestation is in the early stages of the growth, ii) Small white silvery patches are seen all over the leaves which shine in the sun. iii) In severe infestation, whole plants look blemished and turn white.

Cutworm (Spodoptera litura F.): Cutworm is a polyphagous pest, which causes severe defoliation in onion (Atwal and Dhaliwal 2005). The larvae of this insect are seen in nursery beds and newly transplanted onion fields.

It will scrap the chlorophyll content of the leaves and make irregular but large holes. They cut the seedlings at ground level during night and hide inside the tubular leaves during day.

\section{Eriophyid mite (Aceria tulipae Keifer)}

Tulipae also called as wheat curl mite attacks onion in both field and storage condition. Both adults and immature ones feed on young leaves and infested leaves do not open completely. Mite feeding causes stunting, twisting, curling and discoloration of foliage. 
Yellow mottling is seen mostly on the edge of the leaves. This damage has been attributed to various viruses thought to be transmitted by mites. In storage, bulbs dry and desiccate.

\section{Leaf miner (Liriomyza sp.)}

Leaf miners have become serious pests on Allium sp. in many parts of the world, causing economic damage to onion (Chen et al., 2003). Adult females make repeated punctures in leaf tissue with their ovipositor and feed the plant exudates. These punctures may be the first sign of damage. Larvae mine leaves, and move towards into bulbs and leaf sheathes. Both the leaf punctures and mines serve as entry routes for bacterial and fungal pathogens.

\section{Onion fly/ maggot (Delia antique)}

The infected onion leaves gets rotten, shredded and rolled up. Growth of onion tubers gets hampered, tissues get decayed and become unfit for marketing. The long whitish colour eggs are laid on the undersurface of onion near the soil.

\section{Diseases}

\section{Purple blotch (Alternaria porri)}

Purple blotch of onion is a problem particularly during cooler months as the disease spreads rapidly under favourable climatic conditions causing serious yield losses (Gupta et al., 1981). Humid climate with temperature ranging from 18 to $30{ }^{\circ} \mathrm{C}$ and relative humidity of $80-90 \%$ favours the disease development. On leaves eye shaped, purple colour spots develop which are surrounded by a broad chlorotic margin. These spots are very prominent on the flower stalk. The lesions girdle the leaves and stalks and cause drying which drop after 2-3 weeks. The infected plants fail to develop bulbs. Older leaves are more susceptible to the disease. Yield loss range from $20-25 \%$ and the severity of purple blotch in onion is always higher in fields with onion thrips (Thind and Jhooty, 1982, Yasodha and Natarajan, 2008).

\section{Stemphylium leaf blight (Stemphylium vesicarium)}

Stemphylium blight commonly affect onion crop causing considerable damage (Mathur and Sharma, 2006). Warm $\left(18-25^{\circ} \mathrm{C}\right)$ humid conditions and long periods of leaf wetness (16 hours or more) favours the disease development. Infection occurs on radial leaves of transplanted seedlings at 3-4 leaf stage during late March and early April. The symptoms appears as small yellow to orange flecks or streaks in the middle of the leaf which soon develop into elongated, spindle shaped to ovate elongate diffused spots surrounded by characteristic pinkish margin. The spots progress from the tip to the base of the leaves. The spots coalesce into extended patches, blighting the leaves and gradually the entire foliage.

\section{Basal rot (Fusarium oxysporum f. sp. cepae)}

Basal rot is an economically important disease of onion and generally occurs when the soil is moist and warm (optimum 27-29 $\left.{ }^{\circ} \mathrm{C}\right)$. The early symptoms in the field are yellowing of leaf tips and stunted growth, which later on dry from tip downwards. As the disease progresses, the whole plant collapse and, if the plant is pulled, it often comes out without any roots attached because they have decayed. If infection occurs late in the season, the symptoms may not show up until the onions are in storage because of latent infections (Brayford, 1996). Pathogen survives in soil and onion bulb in the form of chlamydospore for many years. Yield losses of 25-35\% due to Fusarium basal rot have been reported in onion (Lacy and Roberts, 1982). 
Colletotrichum blight /anthracnose/ twister disease (Colletotrichum gleosporiodes)

The fungus can survive for many years as sclerotia in the soil or for shorter periods in infected plant debris. Disease is most severe in warm $\left(25-30^{\circ} \mathrm{C}\right)$, moist soils that are high in organic matter. The characteristic symptoms of this disease are curling, twisting, chlorosis of the leaves, and abnormal elongation of neck (false stem). Initially pale yellow water soaked sunken lesions appears on leaf blades. Numerous black coloured slightly raised structures are produced in the central portion, which may be arranged in concentric rings. The affected leaves shrivel, droop down and finally wither.

\section{Downy mildew (Peronospora destructor)}

Warm and humid climate favours the development of disease. Fungus survives in soil and infected plant debris. Cottony white mycelial growth appears on leaves. Infected leaves turn to pale green and gradually turn pale yellow to dark brown and dries up.

\section{Bacterial soft rot (Erwinia carotovora)}

This disease is favored by warm, humid conditions with an optimum temperature range of 20-30 ${ }^{\circ} \mathrm{C}$. However, during storage or transportation, soft rot can develop when temperatures are above $30{ }^{\circ} \mathrm{C}$. The main sources of inoculum are contaminated soil and crop residues.

The bacterium also spread by splashing rain, irrigation water and insects. Bacterial soft rot is a main problem on mature bulbs. Affected scales first appear water-soaked and pale yellow to light brown. As the soft rot progresses, invaded fleshy scales become soft and sticky with the interior of the bulb breaking-down. A watery, foul-smelling thick liquid can be squeezed from the neck of diseased bulbs.

\section{White rot (Sclerotium cepivorum)}

This disease is most severe in cool and dry soils. Fungus survives in soil as sclerotia for many years. The initial symptoms are yellowing and dieback of leaf tips. Later, scales and roots get destroyed. The bulbs become soft and water soaked. White fluffy or cottony growth of mycelium with abundant black sclerotia develops on the infected bulbs.

\section{Pink root (Pyrenochaeta terrestris)}

The fungus spreads through soil and irrigation water. Optimum temperature for growth of this pathogen is $24-28^{\circ} \mathrm{C}$. The affected roots turn yellow, shrivel and die, meanwhile taking on a distinct pink colour. The affected bulb gets retarded. In severe cases, the roots may die and the plants become weakened or stunted, especially in drier areas of the field. Crop suffering from heat or drought stress due to poor soil is more prone to yield losses.

\section{Damping off (Pythium aphanidermatum)}

The disease is more prevalent during Kharif season/rainy season and causes about 60-75\% damage. High soil moisture and moderate temperature along with high humidity leads to the development of the disease. Pathogen(s) survives on infected crop debris and soil which are primary source of inoculum. Two types of symptoms are observed. i). Pre-emergence damping-off: seed and seedling get rottened before they emerge out of the soil. ii) Postemergence damping-off: the pathogen attacks the collar region of seedlings on the surface of soil. The collar portion rots and ultimately the seedlings collapse and die and infected tissues appear soft and water soaked.

\section{Onion yellow dwarf (OYD)}

Onion yellow dwarf caused by Onion yellow $d$ warf virus (OYDV) is carried by infected seed bulbs, onion sets and volunteer onions. Many aphid species can transmit this virus from infected to healthy plants. Yellow streaks at the bases of the first true leaves are the first symptoms of this disease. After these initial 
symptoms, all leaves show yellow streaks to complete yellowing of leaves. Leaves are sometimes crinkled and flattened and tend to fall over. Bulbs are undersized.

\section{Iris yellow spot disease (IYSD)}

Iris yellow spot disease is caused by Iris yellow spot virus (IYSV) which is transmitted by thrips in a persistent manner. Disease severity is positively correlated with thrips populations in the field. This virus is not seed transmitted. The symptoms first appear as straw-coloured, dry, tan, spindle or diamond-shaped lesions, with or without distinct green centers with yellow or tan borders on leaves. The symptoms are more pronounced on flower stalks. Infected leaves and stalks lodge during the latter part of the growing season. Over-wintering onions, infected transplants and alternate hosts can serve as sources of both vector and virus.

\section{Black mould (Aspergillus niger)}

Black mould caused by is most common when temperatures are higher than $30^{\circ} \mathrm{C}\left(86^{\circ} \mathrm{F}\right)$ in the field or $24^{\circ} \mathrm{C}$ in storage. Spores of this fungus are very common in the air and soil which serve as the source of infection. Infected bulbs show black discoloration at the neck and streaks.

The black mycelium and conidia of this fungus are seen beneath the outer dry scales. In advanced stages all scales are infected and the bulb gets shriveled.

\section{Integrated pest and disease management cultural practices}

Growing two rows of maize or inner row of wheat and outer row of maize as barrier crops around field border at least 30 days before onion planting.

Selection of disease free bulbs for planting.

Deep ploughing in hot summer, regular hoeing, flooding of infested field and clean cultivation.
The field should be well drained and free from weeds.

Crop rotation of 4-5 years with non-host crop will help to reduce basal rot, white rot, pink root rot and Iris yellow spot disease.

Mixed cropping with tobacco and sorghum is effective to manage basal rot incidence.

Solarization of soil at high temperature reduces the white and pink root rot incidence.

Growing of small onion under drip irrigation system.

\section{Biological control}

Bulb treatment with Pseudomonas fluorescens @ $5 \mathrm{~g} / \mathrm{kg}+$ Trichoderma viride @ $5 \mathrm{~g} / \mathrm{kg}$.

Soil application of P. fluorescens @ $1.25 \mathrm{Kg} / \mathrm{ha}$ +T.viride@1.25 kg/ha + AM Fungi@12.5 kg/ha+Azophos@4kg/ha+Neem cake@ $250 \mathrm{~kg} / \mathrm{ha}$ at $30 \mathrm{DAP}$.

Installation of yellow sticky traps @ 12 Nos/ha for trapping onion thrips.

Installation of pheromone traps @ 12 Nos /ha for cut worm.

Spray application of P.fluorescens @ $5 \mathrm{~g} / \mathrm{l}+$ Beauveriabassiana@10 g/l on 30 DAP.

Spray application of Azadairachtin 1\% @ 2 ml/l on 40 DAP.

\section{Chemical control}

Seed/ bulb treatment with Thiram or Captan @ $0.3 \%$ and drenching of the nursery beds with captan or thiram@0.2\% or carbendazim @ $0.1 \%$ or copper oxychloride @ $0.3 \%$ for managing damping-off.

Spray insecticide viz., Profenofos @ 0.1\%, Carbosulfan@0.2\% or Fipronil @ 0.1\% to manage onion thrips. 
Need based application of Profenophos @ 2 ml/1 or Dimethoate @ 2 ml/1 or Triazophos@2 $\mathrm{ml} / \mathrm{l}$ for the management thrips/leaf miner/cut worm.

Two to three foliar sprays of copper oxychloride@0.25\% or Chlorothalonil @0.2 \% or Zineb @0.2\% or Mancozeb @0.2\% or Hexaconazole @ 0.1\% or Propiconazole @ $0.1 \%$ at $10-15$ days intervals from 30 days after transplanting for the management of purple blotch, Stemphylium blight and Colletotrichum blight disease.

Dipping onion sets in Carbendazim @ 0.2\% or spraying of Carbendazim @ $0.1 \%$ before harvest minimize the storage loss due to basal rot and white rot.

\section{References}

Acharya, U., Narayan, S.R., Venkatesan, K., Saraswathi, T. and Subramanian, K.S. 2015a. Response on growth, yield and quality parameters of Multiplier Onion (Allium cepa L. var. aggregatum Don.) var. $\mathrm{CO}(\mathrm{On}) 5$ with different doses and method of Zinc and Boron application. Int. J. Ag. and Agric. Res., 6(4): 59-67.

Acharya, U., Venkatesan, K., Saraswathi, T. and Subramanian, K.S.2015 b. Physiological and yield parameters of multiplier onion (Allium cepa L. var. aggregatum don.) var. $\mathrm{CO}(\mathrm{On}) 5$ as influenced by zinc and boron application. Hort. Fl. Res. Spectrum, 4(2): 155-158

Alam, M.N., Abedin, M.J. and Azad, M.A.K. 2010. Effect of micronutrients on growth and yield of onion under calcareous soil environment. Int. Res. J. Pl. Sci., 1: 5661.

Anbukkarasi, V. 2010. Studies on pre and postharvest treatments for extending shelf life in onion (Allium cepa L. var. aggregatum Don.) cv. CO (On) 5. Ph.D (Hort.) Thesis, HC\&RI, TNAU, Coimbatore.

Anbukkarasi, V., Paramaguru, P., Pugalendhi, L., Ragupathi, N. and Jeyakumar, P.
2012. Temperature treatments on postharvest handling of small onion (Allium cepa L. var. aggregatum Don.). Madras Agric. J., 99 (10-12): 673-676.

Anon. 2013. https://www.zauba.com/ export analysis- FRESH + ONIONS + SHALLOT - report.

Aramirtham, R. 2000. Studies on certain aspects of growth and development of seed setting aggregatum onion (Allium cepa $\mathrm{L}$ var. aggregatum). Ph.D Thesis, HC\&RI, TNAU, Coimbatore.

Atwal, A.S., and G.S. Dhaliwal. 2005. Agricultural pests of South Asia and their Management: pests of vegetables. Kalyani Publishers, New Delhi, India.

Ballabh, K. and Rana, D.K. 2012. Response of micronutrients on qualitative and quantitative parameters of onion (Allium cepa L.). Prog. Hort., 44: 40-46.

Boyhan, E., Reid, L., Torrance, Jeff, C., Cliff, R. and Randell, H. 2009. Sowing date, transplanting date, and variety effect on transplanted short-day onion production. Hort. Tech., 19: 66-71.

Brayford, D. 1996. Fusarium oxysporum f. sp. cepae. Mycopathologia, 133: 39-40.

Brewster, J.L. 1994. Onion and other vegetables alliums. $\mathrm{CAB}$ International publications, UK.

Chen, X.X., X.Y. Lang., Z.H. Xu., J.H. He and Y. Ma. 2003. The occurrence of leafminers and their parasitoids on vegetables and weeds in Hangzhouarea, Southeast China. Biol. Control, 48: 515527.

Cho, K., C.S. Eckel, J.F. Walgenbach, and G.G. Kennedy. 1995. Comparison of colored sticky traps for monitoring thrips populations (Thysanoptera: Thripidae) in staked tomato fields. J. Entomol. Sci., 30: 176-190.

Demirel, N., and W. Cranshaw. 2005. Attraction of colour traps to Thrips species (Thysanoptera: Thripidae) on brassica crops in Colorado. Pak. J. Biol. Sci., 8: 1247-1249.

Dhananivetha, M., M.M. Amnullah, P. Murali Arthanari and S. Mariappan. 2017. Weed 
management in onion: A review. Agri. Rev., 38(1): 76-80.

Geetharani, P., Manivannan, M.I. and Ponnuswamy, A.S.2008. Seed production of onion as influenced by the application of growth regulators and nutrients. The Asian J. Hort., 3(2): 301-303.

Gupta, R.P., K.J. Srivastava, U.B. Pandey, and D.J. Midmore. 1994. Diseases and insect pests of onion in India. Acta Horticulture, 358: 265-372

Gupta, R.P., V.B. Pandey, D.K. Srivastava, and L. Singh. 1981. Bioassay of fungicides against Alternaria porri (Ellis) Neerg causing purple blotch of onion. Pesticides, 75: 27-28.

Hortstat. 2011. Department of Horticulture and Plantation Crop, Govt. of Tamil Nadu.

Jawaharlal, M., Sundararajan, S. and Veeraragavathatham, D. 1985. Influence of the method of application of $\mathrm{Zn}$ and $\mathrm{Fe}$ on the major nutrient content of onion. South Ind. Hort., 36(6): 308-12.

Jayabharathi. 1989. Influence of different doses of $\mathrm{N}, \mathrm{P}$ and $\mathrm{K}$ on the yield and quality of aggregatum onion cv. CO 4. Madras Agric. J., 76(3): 150-156.

Kaveri, G. and Thirupathi, V. 2014. Studies on thermal, textural and quality parameters of multiplier $\mathrm{CO} 4$ onion bulb (Allium cepa L.var aggregatum Don.). Madras Agric. J., 101 (10-12): 411-415

Kaveri, G. and Thirupathi, V. 2015. Studies on Geometrical and Physical Properties of $\mathrm{CO} 4$ onion bulb (Allium cepa $\mathrm{L}$ var. aggregatum Don.). Int. J. Recent Sci. Res., 6(3): 2897-2902.

Krishna Kumar, N.K., P.N. Krishnamoorthy, C.M. Kalleshwaraswamy, and H.R. Ranganath. 2008. Management of thrips (Thrips tabaci Lindeman) on organically raised rose onion. Pest Management in Horticultural Ecosystems, 14: 128-132.

Lacy, M. L., and D. L. Roberts. 1982. Yields of onion entries in Midwestern organic soils infested with Fusarium oxysporum f.sp cepae and Pyrenochaeta terrestris. Plant Dis., 66: 1003-1006.

Mahadevaswamy, M. and James Martin, G.
2003. Economics of wide row sugarcane intercropped with aggregatum onion (Allium cepa L var. aggregatum) under garden land conditions. Madras Agric. J., 90(7-9): 426-430.

Mishra, D.K., Gopesh Pathak, R.S. Tailor, and Alok Deshwal. 2007. On-farm trial: an approach for management of thrips in onion. Indian Res. J. Ext. Ed., 7: 66-67.

Misra, A. 2000. Production potential of sugarcane varieties under wide row spacing. In: Ann. Report for 1999-2000. Sugarcane Breeding Institute, Coimbatore, p.54.

Muthuramalingam, S., Sendurkumaran, S., Muthuvel, I., Sathiyamurthy, V.A. and Sankar, V. 2000. Effect of plant density and nutrients on quality characters of seed propagated aggregatum onion (Allium cepa L var. aggregatum) Type Gnanamedu. Allium Improvement Newsletter, 10, 32-35.

Nehra, B.K., Pandita, M.L. and Singh, K. 1992. A note on the effect of various chemicals on bolting and seed yield of onion (Allium cepa L.) under seed to seed method of seed method of seed production. Haryana J. Hort. Sci., 21 (1-2): 103-105.

Ponnuswami, V. and Thamburaj, S. 1996. Shallots seed production. TVIS, 1 (1): 18.

Prabinkumar, S and Visvanathan, R. 2014. Effect of storage temperature on respiration rate of aggregate onion (Allium cepa $\mathrm{L}$ var. aggregatum Don.). Madras Agric. J., 101 (1-3): 93-95.

Rohini, N and P. Paramaguru. 2015a. Effect of planting seasons and genotypes on growth and seed yield of aggregatum onion (Allium cepa L. var. aggregatum Don). Int. J. Agric. Sci. and Res., 5 (6):293-298.

Rohini, N and Paramaguru, P. 2016. Seasons' influence on bulb, seed yield and quality of aggregatum onion, Allium cepa L. var aggregatum. Int. J. Farm Sci., 6(1):174183.

Rohini, N. and P. Paramaguru. 2015b. Influence of planting time on seed yield and quality of Aggregatum onion genotypes (Allium cepa L.var. aggregatum Don). Int. J. 
Environ. Eco. Fam.Ur. St., 5 (6): 29-34.

Santhi, R., Natesan, R. and Selvakumari, G. 2005. Effect of soil fertility and integrated plant nutrition system on yield, response and nutrient uptake by aggregatum onion. Indian J. Agric. Res., 39 (3): 213 - 216

Savitha, V. 2009. Standardization of drip fertigation in onion. Ph.D. Thesis, Tamil Nadu Agricultural University, Coimbatore.

Selvarani, K. and Umarani, R. 2011. Evaluation of seed priming methods to improve seed vigour of onion (Allium cepa cv. aggregatum) and carrot (Daucus carota). J. Agric.Tech., 7(3): 857-867.

Sharma, A. K., and R. K. Seth. 2005. Combined effect of gamma radiation and azadirachtin on the growth and development of Spodoptera litura F. Curr. Sci., 89: 1027-1031.

Sonata, K., S. Aurelija, T. Vytautas, A. Algirdas, Z. Algimantas. 2005. The effectiveness of insecticide Neemazal T/S $1 \%$ E.C. for protection of common China Aster (Callistephus chinensis (L.) seedlings against onion thrips (Thrips tabaci (Lindeman). Rural DevelopmentTechnology of Progressive Farming: Technical and Technological Solutions, 55: 27-28.

Subbiah, K., Helkia, J., Thyagarajan, P. and Manikam, T.S. 1982. Effect of macronutrients on yield, uptake and response of nutrients in onion (Allium cepa L.) var CO 2. South Ind. Hort., 30 (2):124-126

Sumanaratne, J., Pand Palipane, W.M.U. 2002.
Feasibility of small onion (Allium cepa var. aggregatum) cultivation from, true seeds. Ann. Sri Lanka Dept. Agric., 4: 3946.

Sundaram, C.J. 2012. Genetic diversity analysis of onion (Allium cepa L. var. aggregatum Don.) accessions detected through morphological and RAPD markers. M.Sc., Thesis, HC\&RI, TNAU, Coimbatore.

Thilakavathy, S. and Ramaswamy, N. 1998. Effect of inorganic and biofertilizer treatments on yield an dqualit parameters of multiplier onion (Allium cepa var aggregatum). NHRDF-Newsletter, 18(2), $18-20$

Thind, T.S., and J.S. Jhooty. 1982. Association of thrips with purple blotch infection on onion plants caused by Alternaria porri. Indian Phytopathol., 35: 696-698.

Tomar, B.S. 2005. Quality seed production of onion. Seed production unit, New Delhi110012.

Vasilas, B.L., Legsand, D.C. and Wolf.1980. Foliar fertilization of soybean. Absorption and translocation of $15-\mathrm{N}$ labeled urea. Agron. J., 72: 271-275.

Yasodha, P., and N. Natarajan. 2008. Management of onion and garlic thrips (Thrips tabaci) and flower thrips (Frankliniella occidentalis). Rashtriya Krishi, 3: 30-31.

Zen, S., M. Okuda, S. Fuji, and T. Iwanami. 2008. The seasonal occurrence of viruliferous Thrips tabaci and the incidence of Iris yellow spot virus disease on lisianthus. J. Plant Pathol., 90: 511515.

\section{How to cite this article:}

Saraswathi, T., V.A. Sathiyamurthy, N.A. Tamilselvi and Harish, S. 2017. Review on Aggregatum Onion (Allium cepa L. var. aggregatum Don.). Int.J.Curr.Microbiol.App.Sci. 6(4): 1649-1667. doi: https://doi.org/10.20546/ijcmas.2017.604.201 